\title{
Frost/Freeze Protection of Strawberries Grown on Black Plastic Mulch
}

\author{
E.B. Poling ${ }^{1}$, H. Pat Fuller ${ }^{2}$, and K.B. Perry ${ }^{1}$ \\ Department of Horticultural Science, North Carolina State University, \\ Raleigh, NC 27695-7609 \\ Additional index words. Fragaria $\times$ ananassa, annual hill system, sprinkling irrigation
}

Abstract. Floating rowcovers composed of extruded polypropylene, spunbonded polypropylene, and polyester were used in 1987-88 in eastern North Carolina for cold protection of strawberries (Fragaria $\times$ ananassa Duch.) growing in annual hill culture on black plastic mulch. Treatments consisted of floating rowcovers in either winter, spring, or both with and without overhead irrigation for spring frost/freeze protection, in addition to irrigated and nonirrigated unprotected plots. Winter rowcovers increased air temperatures by 1 to $2 \mathrm{C}$ without advancing bloom or harvest date. Significant blossom temperature differences relative to rowcover materials $(\approx 1.5 \mathrm{C})$ and irrigation use $(\approx 1.5$ to 3.0C) were detected over the course of six spring frosts. Time of application of covers (winter or spring) and irrigation in spring interacted in their effects on early yields (25 Apr.-5 May). However, rowcover and irrigation treatments did not have a significant effect on total marketable yield, yield per plant, or berry mass. In the absence of higher prices for early than late-season fruit or of more severe environmental extremes than experienced in the current study, it would be difficult to justify the added expense of rowcovers.

In northern areas with short growing seasons and/or low-temperature stress during winter or spring, spunbonded rowcovers have been shown to advance strawberry harvest and improve strawberry yields in matted rows by increasing the growing degree units and by extending the season, mainly through reducing heat loss from beneath the covers (Pollard et al., 1987; Pollard. and Cundari, 1988; Pritts et al., 1989).

In black plastic mulch production systems in the southeastern United States, strawberry responses to rowcovers after winter and/or spring deployment have differed, -depending on materials used, season of use, and severity of local frost/freezes (Hochmuth et al., 1986; Poling, 1986, 1987). In a North Car-

Received for publication 16 Nov. 1989. Paper no. 12443 of the Journal Series of the North Carolina AgriculturalResearchService, Raleigh, NC 276957643. We appreciate the assistance of William $\mathrm{H}$. Swallow with statistics. We also thank J.B. Earp for his field technical assistance. Materials tested were supplied by: CDK International Corp., Marietta, Ga; E.I. du Pent de Nemours \& Co., Wilmington, Del.; International Paper Co., New York, N. Y.; and Kimberly-Clark Corp., Roswell, Ga. Mention of trade names in this publication is for clarification purposes and does not imply product endorsement or discrimination by the North Carolina Agricultural Research Service. The cost of publishing this paper was defrayed in part by the payment of page charges. Under postal regulations, this paper therefore must be hereby marked advertisement solely to indicate this fact.

'Associate Professor.

${ }^{2}$ Former Graduate Student. olina winter with record low temperatures $(-22 \mathrm{C})$, strawberry plants in annual hill culture on black plastic mulch and covered by spunbonded polyester had significantly less winter injury and higher yields than unprotected plants (Poling, 1986). In a milder winter, however, use of a floating rowcover increased early yields but did not influence total yield (Poling, 1987).

Down to -4 to $-5 \mathrm{C}$, certain rowcovers supply frost protection of strawberry blossoms and fruit equivalent to that provided by the conventional overhead irrigation method (Hochmuth et al., 1986). Production risks associated with overhead irrigation for cold protection include electrical outages, ice damage to plants (Hochmuth et al., 1986), inadequate coverage during advective freezes (Martsolf and Ferretti, 1977), and soil sat-

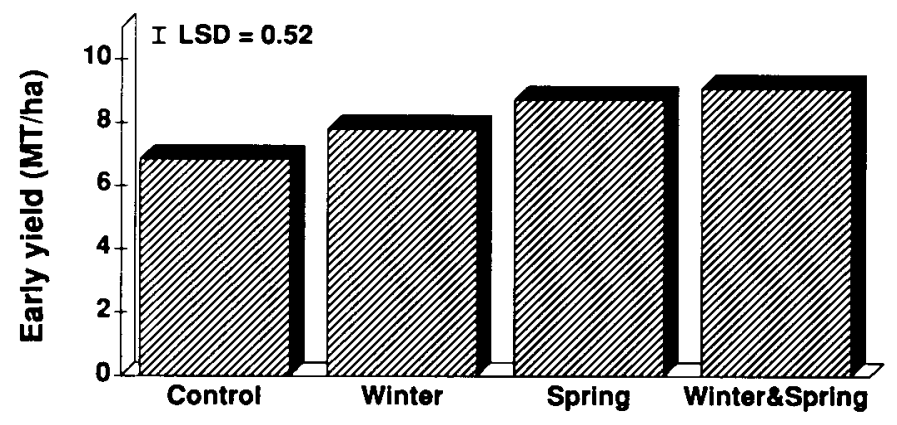

Deployment Period

Fig. 1. Effect of rowcover deployment periods on early strawberry yield. uration. Negative environmental consequences of irrigation are soil erosion and potential contamination of groundwater with leached synthetic fertilizers. Also, there is the need for increased use of fertilizers to compensate for leaching on sandy soils.

The objective of this experiment was to evaluate the potential for avoidance of frost/ freeze damage by using nonwoven floating rowcovers in strawberry production on black plastic mulch in the midsouthern United States. Specifically, we evaluated a) the performance of strawberry plants protected by polyester and polypropylene floating rowcovers, b) the effects of deploying covers in winter and/or spring for frost/freeze protection, and c) the effectiveness of using rowcovers alone or in conjunction with overhead irrigation for spring frost/freeze protection.

The study was conducted in 1987-88 at the Central Crops Research Station, Clayton, N.C. (lat. $35^{\circ} 40^{\prime} \mathrm{N}$, long. $78^{\circ} 30^{\prime} \mathrm{W}$, elevation $106 \mathrm{~m}$ ) on a Norfolk loamy sand with $0.2 \%$ humic matter and $\mathrm{pH} 5.9$. The experimental design was a split-plot randomized complete block consisting of four replicates, with irrigation treatments as main plots and rowcovers and deployment season as subplots. Experimental units consisted of embossed black polyethylene mulch-covered beds $20 \mathrm{~cm}$ high, $71 \mathrm{~cm}$ wide, and $6.1 \mathrm{~m}$ long with $1.5 \mathrm{~m}$ between centers. Green, nondormant 'Chandler' strawberry plants were planted in late Sept. 1987 at a spacing of 25 $\mathrm{cm}$ in-row and $30 \mathrm{~cm}$ between offset double rows (Poling and Durner, 1986). There were 40 plants per plot. Irrigation for frost/freeze protection followed recommendations of the North Carolina Agricultural Extension Service for commercial strawberry production (Poling et al., 1984).

There were two spring irrigation treatments (with or without irrigation), 12 rowcover treatments (four rowcovers $\times$ three deployment periods), and eight controls without rowcovers, for a total of 32 plots per replicate. For each irrigation treatment, rowcovers were deployed during either winter, spring, or both and a control plot without 


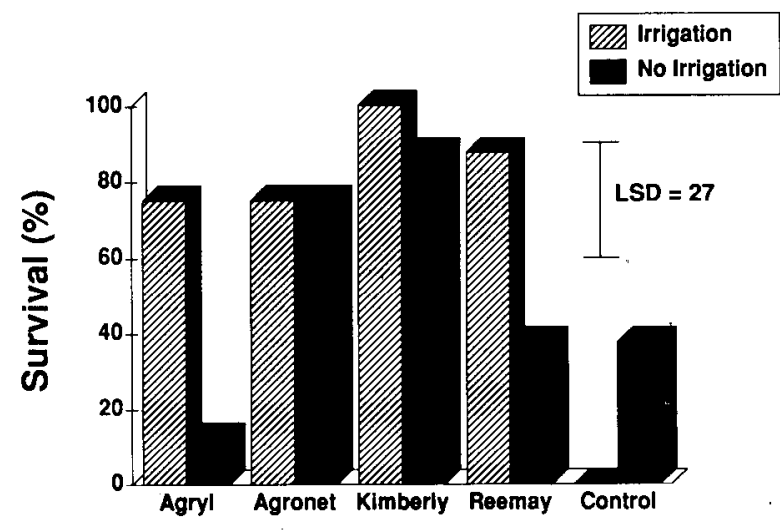

Row Cover

Fig. 2. Effect of irrigation treatments and spring rowcovers on strawberry blossom survival for the frost of 14-15 Mar. 1988. The split plot errors a and $\mathrm{b}$ were pooled, giving a single LSD ( $P=0.05)$ for comparing irrigation treatments within rowcover or rowcovers within irrigation treatment.

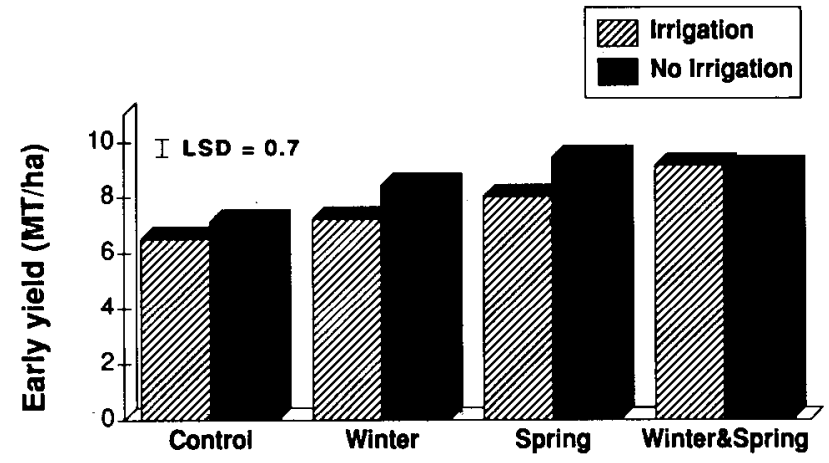

\section{Deployment Period}

Fig. 3. Effect of irrigation treatments and rowcover deployment period on early strawberry yield. The split plot errors $\mathrm{a}$ and $\mathrm{b}$ were pooled, giving a single LSD $(P=0.05)$ for comparing irrigation treatments within deployment period; winter or spring vs. control or winter and spring within irrigation treatment.

rowcovers was randomly assigned to each rowcover type.

Four types of rowcovers were used: 6.1$\mathrm{m}$ widths of the spunbonded polyester Reemay S-2006 (R) (21 g.m $\mathrm{m}^{-2}$ ) (Reemay, Old Hickory, Term.); two types of spunbonded polypropylene, Agryl P-17 (AG) $\left(17 \mathrm{~g} \cdot \mathrm{m}^{-2}\right)$ (International Paper Co., New York, N.Y.) and Kimberly Farms floating rowcover $(\mathrm{K})$ $\left(21 \mathrm{~g} \cdot \mathrm{m}^{-2}\right)$ (Kimberly-Clark Corp., Roswell, Ga. ); and an extruded polypropylenepolyamide Agronet L/L (AN) (14 $\left.\mathrm{g} \cdot \mathrm{m}^{-2}\right)$ (manufactured by Beghin Say, Kaysersberg, France, and distributed in the United States by CDK International, Marietta, Ga.). On 14 Dec. 1987, covers were applied to plots designated to receive winter rowcovers. The covers were anchored to the ground with soil and wire pins. Each cover enclosed three 6.1$\mathrm{m}$ plots, with the center row used as the experimental subplot for data collection.

At 5-min intervals during the winter, air temperatures -were monitored under each rowcover and within the uncovered control using copper-constantan, 20-gauge $(0.8 \mathrm{~mm}$ in diameter) thermocouples connected to CR21X microloggers (Campbell Scientific, Logan, Utah). One sensor was placed in each experimental unit selected for winter temperature measurements. Air temperature sensors were mounted in white, wooden vented shelters $\approx 7 \mathrm{~cm}$ above the bed surface.

Rowcovers were removed on 24 Feb. 1988 from all plots when plants began to bloom, indicating the end of the winter deployment period. Covers on plots requiring only winter deployment were removed and never replaced, while some covers were furled in alleys between beds and left adjacent to those plots requiring spring frost/freeze deployment in addition to winter deployment. Others were placed adjacent to plots that had been left uncovered during winter but that required spring deployment. At the time of rowcover removal, counts were made of open, living blossoms and of dead blossoms for 20 plants selected randomly from each rowcover treatment.

Beginning with the first spring frost (15 Mar., minimum air temperature - 4.1C), rowcovers and overhead irrigation were applied to the appropriate plots. Once started, irrigation was continued until blossoms were above - 1.1C. Rowcovers remained in place from 14 to 23 Mar. 1988. For spring treatments, temperatures of two open blossoms on different plants were monitored at 5-min intervals during each night of frost protection. The thermocouples were inserted $\approx 2$ to $3 \mathrm{~mm}$ into strawberry receptacle tissue (above the petals). The monitored blossoms were evaluated for damage after each frost, and the thermocouples in dead blossoms were moved to living blossoms before the next frost occurred.

Marketable fruit were harvested biweekly from 25 Apr. through 31 May 1988. Fruit were weighed and average berry mass was determined from a 25-berry sample. Marketable fruit were defined as disease-free, uniformly shaped berries with a mass of at least $8.0 \mathrm{~g}$. Data were analyzed using analysis of variance (ANOVA) and means were separated using the LSMEANS PDIFF option within the SAS General Linear Models procedure (Freund and Littell, 1981).

Winter covers. Spunbonded rowcovers are reported to advance bloom and harvest in northern matted rows (Pollard and Cundari, 1987); but in our study, overwintering covers did not advance bloom, despite some increases in winter microclimate temperatures. Daily average (mean) and daily minimum air temperatures were increased by all rowcovers, relative-to the uncovered control, but there were no significant differences among rowcovers (Table 1). The daily maximum air temperature was higher for winter covers than for the control, and AG had a significantly higher maximum air temperature than AN, $\mathrm{K}$, or R. Interactions between rowcovers and air, crown, and soil temperatures were not significant.

At the time of rowcover removal (24 Feb.), the number of living, open blossoms in rowcover plots did not differ significantly from the control (data not shown). Compared to the control, overwinter covers did improve early yields (25 Apr. to 5 May) (Fig. 1), but not total marketable yield (data not shown). In this situation, the practical value of having winter rowcovers would depend on obtaining a substantial price premium for the added early crop of $\approx 1 \mathrm{t} \cdot \mathrm{ha}^{-1}$.

In an earlier study in southeastern North Carolina (Poling, 1987), it was similarly difficult to assume an economic benefit related to overwinter cover usage, even though the average temperature for Jan. 1988 approached that of Jan. 1985, when a record low of $-22 \mathrm{C}$ was recorded in eastern North Carolina (data not shown).

Irrigation and spring covers. During the spring frost protection period, overhead irrigation used with each rowcover resulted in higher minimum blossom temperatures than with rowcover alone (Table 2). And blossom survival was generally as good or better when rowcovers were used with irrigation than when used alone. Following the coldest period (15 Mar., -4.1C), high blossom survival rates were obtained for all rowcover materials with sprinkling despite an irrigation system failure from $0610 \mathrm{HR}$ to $0640 \mathrm{HR}$ (daybreak), which resulted in extensive losses in uncovered irrigated plots (Fig. 2). Rowcovers K and AN used alone provided blossom protection equal to that obtained when these covers were used with overhead irrigation; they seemed to offer sufficient protection down to $-4.1 \mathrm{C}$. Blossom survival was lower 
Table 1. Influence of winter covers on daily mean maximum, minimum, and range of air temperatures. ${ }^{2, y}$

\begin{tabular}{lcccc}
\hline \hline & \multicolumn{3}{c}{ Daily temp } \\
\cline { 2 - 5 } Rowcover & Mean & Maximum & Minimum & Range \\
\hline Agryl & $7.2 \mathrm{a}$ & $14.5 \mathrm{a}$ & $2.7 \mathrm{a}$ & $11.8 \mathrm{a}$ \\
Agronet & $7.0 \mathrm{a}$ & $13.4 \mathrm{~b}$ & 2.8 & $10.6 \mathrm{ab}$ \\
Kimberly & $7.3 \mathrm{a}$ & $13.8 \mathrm{~b}$ & $3.4 \mathrm{a}$ & $10.4 \mathrm{~b}$ \\
Reemay & $7.2 \mathrm{a}$ & $13.5 \mathrm{~b}$ & $3.3 \mathrm{a}$ & $10.4 \mathrm{~b}$ \\
Control & $5.9 \mathrm{~b}$ & $11.0 \mathrm{c}$ & $2.1 \mathrm{~b}$ & $8.9 \mathrm{~b}$ \\
SE & 0.1 & 0.3 & 0.2 & 0.5 \\
\hline
\end{tabular}

${ }^{2}$ Air temperature sensors mounted in vented wooden shelters $7 \mathrm{~cm}$ above the bed surface and beneath the floating rowcover.

${ }^{y}$ Means represent 792 observations over four replications; Means within a column having the same letter for a temperature measurement are not significantly different (LSD, $P=0.05$ ).

Table 2. Effect of irrigation treatments and spring covers on minimum strawberry blossom temperatures.

\begin{tabular}{lcc}
\hline \hline & \multicolumn{2}{c}{ Minimum temp $\left({ }^{\circ} \mathrm{C}\right)^{2}$} \\
\cline { 2 - 3 } Spring cover & Irrigation & No irrigation \\
\hline Agryl & $-0.2 \mathrm{bc}$ & $-2.8 \mathrm{f}$ \\
Agronet & $-0.5 \mathrm{c}$ & $-2.6 \mathrm{ef}$ \\
Kimberly & $0.6 \mathrm{a}$ & $-2.0 \mathrm{de}$ \\
Reemay & $0.2 \mathrm{ab}$ & $-2.5 \mathrm{ef}$ \\
Control & $-1.8 \mathrm{~d}$ & $-3.2 \mathrm{f}$ \\
\hline
\end{tabular}

'Means within a column or row having the same letter for minimum temperature measurement are not significantly different. The split plot errors a and $\mathrm{b}$ were pooled, giving a single LSD of $0.6(P$ $=0.05$ ) for comparing means.

for $A G$ and $R$ without than with irrigation.

Given the severity of blossom losses in unprotected plots during the 14-15 Mar. (Fig. 2) and 16-17 Mar. freezes (data not shown), we cannot explain the lack of treatment differences for total marketable yield and berry mass. However, significant interactions were observed among winter covers, spring covers, and spring irrigation treatments on early yields (25 Apr.-5 May). Overhead irrigation reduced early yields of winter (W) and spring (S) rowcover plots by $\approx 14 \%$ relative to similar nonirrigated plots (Fig. 3). However, early yields of the control and winter and spring (WS) cover plots were unaffected by sprinkling.

Without further investigation, it is difficult to explain the phenomenon of early yields of $\mathrm{W}$ and $\mathrm{S}$ cover plots being negatively influenced by sprinkling, and not the control and WS deployment plots (Fig. 3). During the spring frost protection in $1988, \approx 30 \mathrm{~cm}$ of water was applied to plots receiving overhead irrigation, creating very wet fields and perhaps an anaerobic soil environment. But, it is inconsistent to suggest a waterlogging response in the $\mathrm{S}$ irrigated plots and not in the WS irrigated plots.

In general, plots covered in spring and in winter and spring gave higher early yields than uncovered plots or those covered only in winter (Fig. 1). But, the ANOVA for early yields also revealed interactions among rowcover materials and deployment periods. With $\mathrm{K}$ and $\mathrm{AG}$, higher early yields resulted with either WS or S deployment compared to Wor no cover in winter and spring (data not shown). AN performed best when used during winter and spring (WS) rather than in either season alone. There were no significant early yield differences among deployment periods (W, WS, or S) for R covers.

To summarize, total marketable yield was unaffected by rowcovers and deployment methods. And without premium prices for the early vs. mid- and late-season crop, it would be difficult to justify the expense of rowcovers for just one season of use in strawberry production on black plastic mulch in the midsouthern United States. In seasons of more-severe winter extremes, rowcovers have shown economic advantage (Poling,
1986), and they have recently been deployed to control blossom and bud losses during latewinter advective freezes in areas where sprinkling is not a viable option (Poling, 1991).

\section{Literature Cited}

Freund, R.J. and R.C. Littell. 1981. SAS for linear models: A guide to the ANOVA and GLM procedures; SAS Institute, Cary, N.C.

Hochmuth, G.J., S.R. Kostewicz, and S.J. Locascio. 1986. Row covers for freeze protection of strawberries. Proc. Natl. Agr. Plastics Congr. 19:175-184.

Martsolf, J.D. and P.A. Ferretti. 1977. Sprinkling for frost protection. Amer. Veg. Grower \& Greenhouse Grower 25:23, 76 .

Poling, E.B. 1986. Effects of winter row covers on the economics of annual hill strawberry production.Proc. Natl. Agr. Plastics Congr. 19:185192.

Poling, E.B. 1987. Preliminarytesting with Agronet in winter and spring protection of strawberries in southeastern North Carolina. Proc. Natl. Agr. Plastics Congr. 20:187-192.

Poling, E.B. 1991. The annual hill planting system in southeastern North Carolina. In: A. Dale and J.J. Luby (eds.). The strawberry into the 21st Centiury. Timber Press, Portland, Ore. (In press.)

Poling, E.B. and E.F. Durner. 1986. Annual hill system culture of strawberries in southeastern North Carolina. HortScience 21:240-242.

Poling, E.B., R.K. Jones, K.A. Sorensen, R.E. Sneed, A.R. Bonanno, K.B. Perry, and M.J. Ast. 1984. Commercial strawberry production in North Carolina. North Carolina Agr. Ext. Serv. Bul. AG-05.

Pollard, J.E. and C.M. Cundari. 1987. Improving strawberry fruit production with floating rowcovers. Proc. N. Amer. Strawberry Growers Assn. 6:89-99.

Pollard, J.E. and C.M. Cundari. 1988. Over-wintering strawberry plants under rowcovers increases fruit production. HortScience 23:332333.

Pollard, J. E., J.B. Loy, and O.S. Wells. 1987. A simple method for evaluating thermal transmission properties of plastic polymers for use as rowcovers. Proc. Natl. Agr. Plastics Congr. 20:193-199.

Pritts,M.P.,K.A.Worden, and M.E. Sheavly. 1989. Rowcover material and time of application and removalaffectripeningandyieldofstrawberries. J. Amer. Soc. Hort. Sci. 114(4):531-536. 